\title{
Is The Level Of Development Significant For The Theory Of Factor Price Equalization?
}

Giuliana Campanelli Andreopoulos (E-mail: andreopoulosg@wpunj.edu), William Paterson University Alexandros Panayides ${ }^{1}$ (E-mail: panayidesa@wpunj.edu), William Paterson University

\begin{abstract}
The vast part of the literature on wages and employment in global markets focuses on international trade considerations and on industrialized countries, often leaving aside developing countries' experiences. The scope of this paper is to examine wages and employment in global markets from a different perspective: we try to combine international trade considerations (trade liberalization) with domestic factors in developing countries. The main idea behind this approach is that the level of development and the complementarity between skilled and unskilled labor are crucial to understand changes in employment and the wage gap.
\end{abstract}

\section{Introduction}

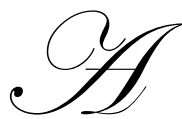

key issue of the debate on globalization is the impact of trade liberalization on the labor market, particularly on wages and employment. The problem with the existing literature is that it focuses on international trade considerations and on industrialized countries, often leaving aside and developing countries. The scope of this paper is to expand the existing literature by including domestic factors and by examining developing countries too. We argue that the level of development and the consequent structure of the labor market as well as the complementarity between skilled and unskilled labor are crucial to understand some controversial results on employment growth and the wage gap.

\section{Literature Review}

The literature on globalization mainly deals with the following two empirical results related to developed countries. First, the demand for skilled labor has increased relatively to unskilled, and second the wage gap between the skilled and unskilled labor has increased as well.

There exist two main explanations of the two above results. On the one side, Katz (1992), Baghwati and Kosters (1994), Sachs and Shatz (1994), Wood (1995, 1998), argue that these phenomena are due to the inability of the developed countries to compete on global markets and on the other side are those who argue that international trade has played a small role, Krugman and Lawrence (1994), Lawrence and Slaughter (1993), and Leamer (1993, 1994).

The first type of explanation mainly based on trade considerations focus on the H.O.S.S. (Heckscher-OhlinSamuelson-Stopler) model with two countries (North and South) one factor of production (labor) of two types (skilled and unskilled) and two goods (skilled intensive and unskilled intensive labor products). The North has a higher proportion of skilled labor, while the South has a relative higher proportion of unskilled labor. According to this model, trade liberalization will have the following effects on the two countries: The North will specialize in the production of skilled intensive labor commodities and consequently there will be an increase in the demand for skilled labor and thus a rise in its wage. Vice versa, the South will move towards an unskilled intensive labor

\footnotetext{
1 Contact author
} 
production with a consequent increase in the demand for unskilled labor and thus a rise in its wage. The final outcome for the employment of unskilled labor will be an increase in the South and a reduction in the North, while for the wage inequality the South should experience a reduction and the North an increase. These will then lead to a North-South convergence in wages.

On the other side of the explanation, Krugman and Lawrence (1994), Lawrence and Slaughter (1993), and Leamer $(1993,1994)$ argue that the main reasons for the increase in the wage gap between skilled and unskilled labor and the loss of unskilled labor oriented jobs are mainly internal such as labor saving technical progress and the shift from manufacturing to services.

The same type of arguments can be found in the contributions on the effects of trade liberalization on employment and wages in developing countries. The two most comprehensive studies on the aggregate level are Wood (1994) and Ghose (2000). In this paper, we use some of the controversial results found by Ghose (2000) as a basis for our theoretical investigation.

\section{Theory}

In this part, we try to analyze the effects of international trade on the labor market. We argue that employment and wages are not only influenced by trade but by demand, supply and institutional factors in the relevant product and factor markets. The level of development affects the conditions and the structure of the labor market. Developing countries are characterized by a large surplus of labor and a dualistic structure of the labor market: the formal and informal market. The surplus of labor mainly comes from rapid population growth, high levels of underemployment in agriculture, and urban unemployment.

Considering the dualistic structure of the labor market there are many differences between these two markets. In general an informal market is characterized by lower wages, unskilled labor, lack of regulations and collective bargaining relatively to the formal. Most of the exporting industries in developing countries employ their unskilled labor from the informal market, while import competing industries employ their skilled labor from the formal market.

We assume that in a developing country the market for unskilled labor can be represented using the usual graph for a competitive market. The demand for labor is a negative function of real wages (and coincides with the marginal productivity of labor, which in this case is decreasing). The supply of labor is not straightforward. According to Lewis' model there is a relationship between the stage of development and the shape of the labor supply. In particular, one can assume that the supply of labor is horizontal at early stages of development because of the enormous surplus of labor, particularly in agriculture. This then implies constant wages in the presence of a shift in the demand for labor. As the country develops and the modern sector (industry) grows, the surplus of labor is reduced and consequently the supply of labor becomes a positive function of real wages. As a result the wages are no longer constant if there is a shift in the demand. In this paper we only consider the upper sloping part of the supply curve since we are investigating countries with a long-term successful export performance in the industrial sector. Needless to say in this case, the effect of an increase in trade on wages and employment depends, ceteris paribus, on the slope of the supply curve.

Consider Figure 1, which represents the competitive market for labor. If we assume an increase in production due to trade liberalization and a consequent shift in the demand for labor, the economy will move from the initial equilibrium point $A$ to point $D$ along the same supply curve $S_{0}$. However, in a developing country with a large surplus of labor this may produce a simultaneous shift in the supply curve to the right which would result in a reduction of wages and a further increase in employment (from point $\mathrm{D}$ to point $\mathrm{C}$ ). The lower the level of development the greater the shift in the supply and thus the reduction in wages relatively to point D. Hence, the effect on wages and employment depends on the relative shift as well as the slope of both demand and supply curves. 
Figure 1

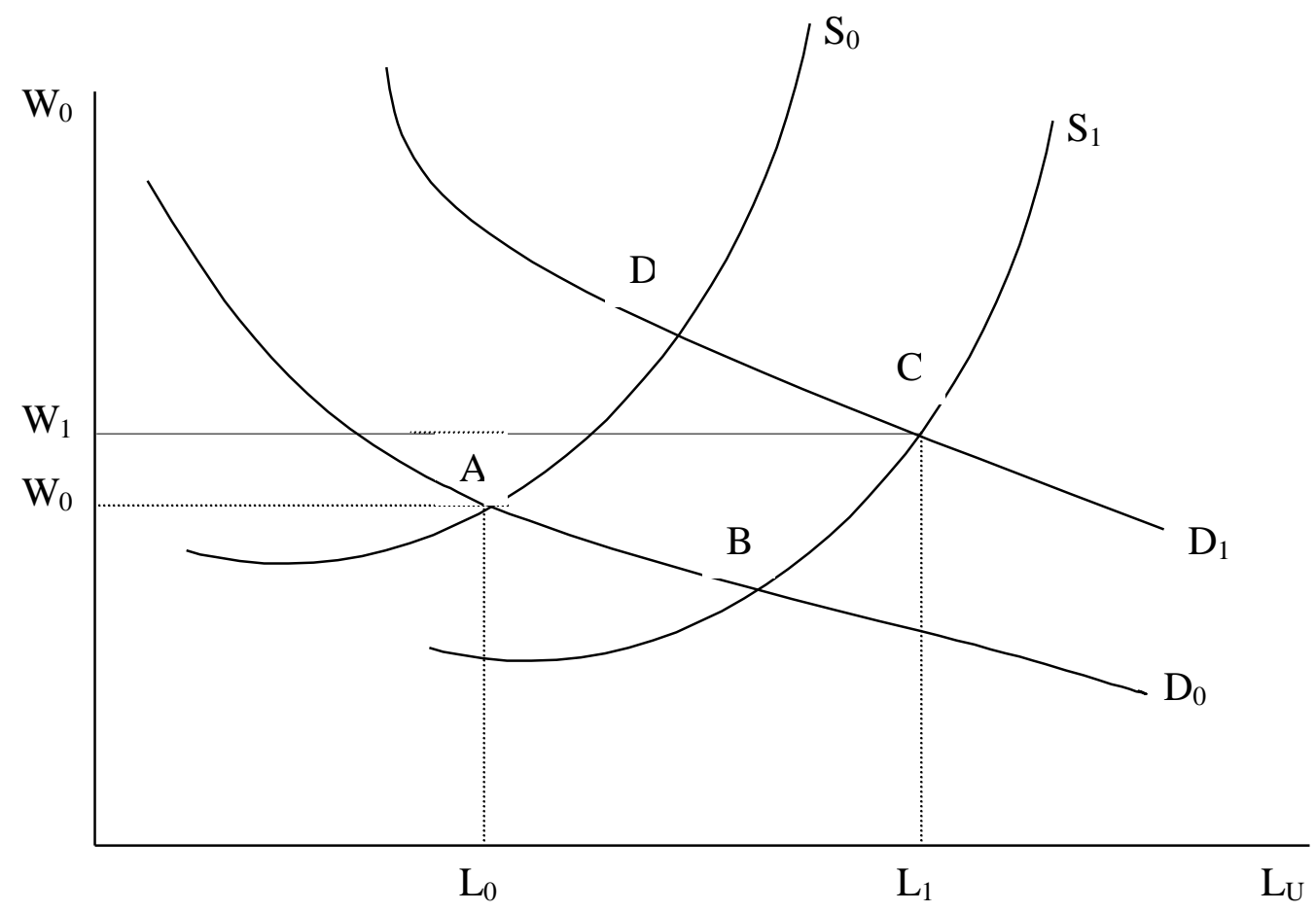

Turning now to the skilled labor we are assuming that it is primarily employed in formal markets, where wage determination and changes in wages do not depend on demand and supply forces but on institutional factors. In developing countries, there is a scarcity of skilled labor but, in contrast to the existing literature, we don't assume a reduction in the employment of skilled labor during the development process for the following two reasons: first, specialization in production may not be complete, and second skilled and unskilled labor might be complements within a particular sector rather than substitutes as most of the literature assumes.

In summary, if one assumes a rapid increase in the demand for labor due to an increase in trade in a country at a low level of development associated with a large surplus of labor and a vast informal market, the wage gap between skilled and unskilled labor may increase instead of decrease as suggested by the theory. Therefore, a factor price equalization reversal may occur.

\section{Empirical Evidence}

We examine some of the countries that were able to benefit from trade liberalization - Taiwan, Korea, China, Malaysia, Taiwan, Philippines, Indonesia and India. These countries are ranked according to the level of development based on GNP per capita in US dollars. The choice of these countries was based on the availability of the data. ${ }^{2}$

The main results on employment are summarized in Table 1.

\footnotetext{
2 For this point see Ghose (2000).
} 
Table 1: Annual Average Rate Of Growth Of Employment

\begin{tabular}{|c|c|c|c|}
\hline & $\underline{\text { Period }}$ & $\underline{\text { Export Oriented Industries }}$ & Import Competing Industries \\
\hline Taiwan & $1980-96$ & 1.7 & 2.9 \\
\hline Korea (Rep. of) & $1981-95$ & 1.8 & 6.8 \\
\hline Malaysia & $1981-95$ & 8.1 & 10.8 \\
\hline Thailand & $1986-94$ & 14.4 & 10.5 \\
\hline Philippines & $1983-87$ & 2 & -5.5 \\
\hline China & $1980-96$ & 7.5 & 4.5 \\
\hline Indonesia & $1981-96$ & 13.1 & 9.9 \\
\hline India & 1987-94 & $1.9^{3}$ & 2.5 \\
\hline
\end{tabular}

One can see from Table 1 that there are sharp difference in their performances. In particular, countries at higher levels of development like Korea, Taiwan, and Malaysia show a relatively faster growth of skilled labor. All the other countries at lower levels of development show the opposite result: a relatively faster growth of unskilled labor. Thus, the empirical evidence seems to confirm the expected result of a faster growth of unskilled labor in labor abundant economies. In addition, in every country (except the Philippines) employment of both types of labor has increased implying a complementarity between skilled and unskilled labor within the manufacturing sector as well as a non-complete specialization.

The results on wages and the wage gap are given in Table 2.

Table 2: Index Of Wage Inequality

\begin{tabular}{|c|c|c|c|c|c|c|c|}
\hline$\underline{\text { Period }}$ & $\underline{\text { India }}$ & $\underline{\text { Indonesia }}$ & $\underline{\text { Korea }}$ & $\underline{\text { Malaysia }}$ & $\underline{\text { Taiwan }}$ & Thailand & Philippines \\
\hline 1980 & & & & & 1.406 & & \\
\hline 1981 & 1.525 & 1.687 & 1.291 & 1.283 & 1.378 & & \\
\hline 1982 & 1.518 & 1.69 & 1.275 & 1.259 & 1.332 & 1.437 & \\
\hline 1983 & 1.513 & 1.718 & 1.298 & 1.275 & 1.304 & & 1.545 \\
\hline 1984 & 1.555 & 1.963 & 1.261 & 1.27 & 1.294 & 1.593 & 1.455 \\
\hline 1985 & 1.574 & 1.91 & 1.27 & 1.29 & 1.319 & & 1.416 \\
\hline 1986 & 1.605 & 1.828 & 1.25 & 1.314 & 1.329 & 1.373 & 1.366 \\
\hline 1987 & 1.621 & 1.899 & 1.264 & 1.318 & 1.302 & & 1.477 \\
\hline 1988 & 1.573 & 1.94 & 1.2 & 1.303 & 1.316 & 1.482 & 1.628 \\
\hline 1989 & 1.676 & 1.797 & 1.232 & 1.253 & 1.317 & 1.265 & 1.575 \\
\hline 1990 & 1.645 & 1.648 & 1.177 & 1.205 & 1.318 & 1.466 & 1.568 \\
\hline 1991 & 1.683 & 1.801 & 1.169 & 1.194 & 1.318 & 1.491 & 1.661 \\
\hline 1992 & 1.73 & 1.647 & 1.169 & 1.186 & 1.308 & & 1.575 \\
\hline 1993 & 1.722 & 1.701 & 1.144 & 1.172 & 1.259 & 1.389 & 1.563 \\
\hline 1994 & 1.742 & 1.74 & 1.109 & 1.156 & 1.213 & 1.172 & 1.565 \\
\hline 1995 & & 2.008 & 1.118 & 1.151 & 1.216 & & 1.424 \\
\hline 1996 & & 1.857 & & & 1.2 & & 1.537 \\
\hline 1997 & & & & & & & 1.543 \\
\hline
\end{tabular}
3 If one adds the figure for Food Beverage and Tobacco, which is an unskilled intensive sector, the figure will be higher and approximately
equal to that of the import competing industry. 
Table 2 shows noticeable differences between the developing countries considered. In particular, countries at the high levels of development (Korea, Taiwan, and Malaysia) show a reduction in the wage gap, which seems to confirm the theory of the Factor Price Equalization. However, the two countries at the lowest level of development, Indonesia and India, show an increase in the wage gap contrary to the predictions of the theory. In addition, both types of wages increased in all the countries.

Recalling the considerations made in the theory section, we argue that the relatively larger surplus of labor and the existence of the informal labor market are the main domestic reasons explaining the increase in the wage inequality.

\section{Conclusion}

In this paper we have tried to fill in some of the gaps in the literature on the effect of globalization on wages and employment by examining the performance of selected developing countries. We argue that the surplus of labor, the dualistic structure of the labor market, and the complementarity of skilled and unskilled labor are important factors in determining changes in employment and wages. We claim that the relatively lower level of development can be a significant factor in explaining the Factor Price Equalization reversal.

\section{References}

1. Bhagwati, J., and M. H. Kosters, D., (eds.) 1994. Trade and Wages: Leveling Wages Down? Washington: AEI Press.

2. Ghose, A. 2000. Trade Liberalization and Manufacturing Employment. Geneva: International Labour Office.

3. Katz, L. F. 1992. "Understanding Recent Changes in the Wage Structure", NBER Reporter (Winter): 10-15.

4. Krugman, P. 1995. "Growing World Trade: Causes and Consequences", Brookings Papers on Economic Activity 95: Issue 1, $25^{\text {th }}$ Anniversary Issue, 327-362.

5. $\quad$ Krugman, P., and R. Z. Lawrence. 1994. "Trade Jobs and Wages". Scientific American 270: 44-49.

6. Lall, S. 2002. "The Employment Impact of Globalization in Developing Countries", QEH working paper series: 93: 1-22.

7. Lawrence, R., and M. J. Slaughter. 1993. "International Trade and American Wages in the 1980s: Giant Sucking Sound or Small Hiccup", Brookings Papers on Economic Activity 2: 161-226.

8. Leamer, E. E. 1993. "Wage Effects of a U.S.-Mexican Free Trade Agreement", in P. M. Garber (eds.), The Mexico-U.S. Free Trade Agreement. Cambridge: MIT Press.

9. Leamer, E. E. 1994. Trade, "Wages and Revolving Door Ideas", NBER working paper No. 4716.

10. Sachs, J., and H. J. Shatz. 1994. "Trade and Jobs in U.S. Manufacturing", BPEA 1: 1-69.

11. Samuelson, P. A. 1948. "International Trade and the Equalisation of Factor Prices", The Economic Journal 58: 163-184.

12. Samuelson, P. A. 1949. "International Factor-Price Equalisation Once Again", The Economic Journal 59: 181-197.

13. Samuelson, P. A., and W. F. Stolper. 1941. "Protection and real wages". Review of Economic Studies 9: 58-73.

14. Todaro, M., and S. C. Smith. 2003. Economic Development. Boston: Addison Wesley.

15. Wood, A. 1994. North-South Trade, Employment and Inequality. Oxford: Clarendon Press.

16. Wood, A. 1995. "How Trade Hurt Unskilled Workers". Journal of Economic Perspectives 9: 57-80.

17. Wood, A. 1998. "Globalisation and the Rise in Labour Market Inequalities". The Economic Journal 108: 1463-1482. 
Notes 